EDYTA NOWAK-ŻóETY

Akademia WSB

w Dąbrowie Górniczej

TOMASZ BOŻEROCKI

Uniwersytet Wileński

\title{
PLATFORMA E-LEARNINGOWA NARZĘDZIEM W NAUCZANIU ZDALNYM OSÓB DOROSEYCH
}

\begin{abstract}
AвSTRACT. Nowak-Żółty Edyta, Bożerocki Tomasz, Platforma e-learningowa narzędziem w nauczaniu zdalnym osób dorostych [The E-learning Platform as a Tool in Remote Adult Learning]. Studia Edukacyjne nr 50, 2018, Poznań 2018, pp.441-452. Adam Mickiewicz University Press. ISSN 1233-6688. DOI: $10.14746 /$ se.2018.50.29

The authors of the article address issues concerning the teaching of the Polish language of adults living in the Czech Republic, Lithuania and Latvia via remote education, using the e-learning platform. They point to the unique approach of adults to education by means of IT tools (e-learning platform). The aim of the authors' search is to try to answer the question: "Is learning Polish using an e-learning platform effective?" The authors also want to learn about the platform itself as a tool in adult learning.
\end{abstract}

Key words: adult education, long-distance learning, e-learning platform

\section{Wprowadzenie}

Dorosłość to etap w życiu człowieka, który zaczyna się tuż po zakończeniu procesu biologicznego dojrzewania, czyli około dwudziestego roku życia i trwa do późnych lat starości. Dzięki własnemu rozwojowi, dynamice życia i aktywności społecznej człowiek dorosły ma możliwość transgresji, czyli przekraczania własnych granic. Edukacja stanowi zdecydowanie jedną z najistotniejszych aktywności w dorosłości. Postępująca globalizacja i wzmożony rozwój technologiczny wymusiły powstanie nowego społeczeństwa, zwanego społeczeństwem wiedzy. Szybkie uczenie się i otwartość na samokształ- 
cenie stało się jedną z najważniejszych kompetencji we współczesnej epoce cyfryzacji. Dotyczy to całego społeczeństwa, w tym osób dorosłych.

Zdaniem Mieczysława Malewskiego, edukacja to czynność uczenia się i nauczania,

ogół zabiegów kształcących i odpowiadających im czynności poznawczych zorientowanych na osiągnięcie intencjonalnie przyjętych celów rozwojowych, formułowanych w odniesieniu do jednostek, grup społecznych i całych społeczeństw (...) edukację tworzą czynności nauczania i czynności uczenia się (...) ich ranga w procesach edukacji ludzi dorosłych zmieniała się wraz ze zmianą społecznych funkcji, jakie dla tego typu edukacji zakładano ${ }^{1}$.

\section{Tadeusz Aleksander zauważa natomiast, że}

edukacja dorosłych jest coraz większym wyzwaniem, jest bowiem związana z własną odpowiedzialnością i samodyscypliną, w czasach współczesnych, pełnych rozleniwiających pokus otaczającego świata oraz rozprzestrzeniającej się postawy konsumpcyjnej, swobody i wygodnictwa, tworzy się poważne zagrożenie dla kształcenia wymagającego wysiłku i zdyscyplinowania, niemal benedyktyńskiej pracowitości².

Nauczanie i uczenie się za pomocą sieci internetowej nazywane jest popularnie e-learningiem i choć różne są jego formy, to jednak prawdopodobnie coraz rzadziej można spotkać kogoś, kto nie znałby znaczenia tego pojęcia. „E-learning to zmiana filozofii kształcenia - zorientowana na ucznia i oparta na stałym dostępie do wiedzy" ${ }^{3}$. Wydaje się, że nauczanie zdalne, czyli edukacja na odległość realizowana za pomocą łączy internetowych, zaspokaja potrzebę współczesnego społeczeństwa do szerokiego dostępu do informacji i komunikacji. Stanisław Juszczyk dodaje, że

edukacja na odległość jest symboliczną ilustracją potencjalnej komplementarności między postępem technologicznym a imperatywem zapewnienia w niedalekiej przyszłości edukacji podstawowej dla wszystkich ${ }^{4}$.

Kursy zdalne przełamują bariery geograficzne, czasowe i społeczne, tak wynika z danych zgromadzonych w trakcie badań w związku z realizacją projektu Erazmus+ „Wiedza bez barier - innowacyjne metody nauczania osób dorosłych". Jednym z celów projektu realizowanego w latach 2016-2018

${ }^{1}$ M. Malewski, Od nauczania do uczenia się, o paradygmatycznej zmianie w andragogice, Wrocław 2010, s. 45- 46.

2 T. Aleksander, Teoretyczne i praktyczne aspekty edukacji kulturalnej oraz oświaty dorostych, Kraków 2006, s. 153.

3 J.J. Czarkowski, E-Learning dla dorostych, Warszawa 2012, s. 85.

4 S. Juszczyk, Edukacja na odległość, Torun 2003, s. 3. 
było przygotowanie i wdrożenie platformy e-learningowej, na której zostały umieszczone kursy języka polskiego dla osób mieszkających w Republice Czeskiej, Litewskiej i Łotewskiej, którzy często mają polskie pochodzenie. Założono stworzenie kompleksowego systemu kształcenia pozaformalnego dla dorosłych, animowanego przez wykwalifikowaną kadrę nauczycieli oraz samych uczestników kursów z Czech, Litwy i Łotwy, przy aktywnym udziale kadry Akademii WSB, która pełni rolę moderatorów tych prac i ekspertów. Projekt powstał jako odpowiedź na potrzeby organizacji mniejszości polskich za granicą, którzy poszukują kontaktu z językiem polskim, kulturą, tradycją między innymi poprzez kształcenie pozaformalne.

Niniejszy artykuł stanowi próbę odpowiedzi na pytanie: czy platforma e-learningowa może być narzędziem zasadnym w kształceniu osób dorosłych na przykładzie kursów języka ojczystego dla Polaków mieszkających w Czechach, na Litwie i Łotwie.

\section{Platforma e-learningowa jako narzędzie edukacji zdalnej}

Współcześni użytkownicy Internetu uczestniczą $w$ różnych aktywnościach - od oglądania, czytania treści, komentowania, do produkowania treści. Rodzaj aktywności określa poziom cyfrowych kompetencji. Człowiek dojrzały, zdaniem autorów, odkryje motywację do uczenia się nowych technologii tym szybciej, im wcześniej zobaczy sens wykorzystania ich w rozwiązywaniu wyzwań życia prywatnego. Irena Kurasz dodaje, że

korzystanie z sieci komputerowej jest dogodne nie tylko z powodu szybkiego i łatwego dostępu do wiedzy, lecz także dlatego, iż treści w niej umieszczone można w łatwy sposób modyfikować, aktualizować i rozpowszechniać. Kształtując swoją świadomość, jednostka dokonuje wyboru informacji zgodnie z własnymi upodobaniami ${ }^{5}$.

Takie możliwości szybkiego dostępu, a jednocześnie modyfikacji wiedzy daje platforma e-learningowa, która jest aplikacją pozwalającą tworzyć, prowadzić i administrować kursy w ramach kształcenia zdalnego. Stanowi ona zestaw narzędzi informatycznych pozwalających na realizowanie kształcenia na odległość. W Polsce dużą popularnością cieszy się Platforma e-learningowa Moodle. Obecnie „Moodle jest rozpowszechniony za darmo jako otwarte oprogramowanie (open source) zgodnie z licencją GNU GPL" ${ }^{6}$.

${ }^{5}$ I. Kurasz, Edukacja dorostych wobec problemów globalizacji, [w:] Andragogika w ujęciu interdyscyplinarnym, red. Horyń, J. Maciejewski, Wrocław 2007, s. 41.

${ }^{6}$ https://pl.wikipedia.org/wiki/Moodle [dostęp: 02.12.2018]. 
Kursy języka polskiego w ramach projektu Erazmus + „Wiedza bez barier - innowacyjne metody kształcenia osób dorosłych" zostały utworzone na tej właśnie platformie. Dla nauczyciela tworzącego kurs jest to narzędzie niezwykle wygodne, ponieważ zawiera własne edytory tekstów i grafiki, co pozwala na merytoryczne opracowywanie materiałów dydaktycznych bezpośrednio na platformie. Platforma Moodle dysponuje także zestawem "narzędzi" do tworzenia różnorodnych aktywności dla uczestników kursów. Dobrze zaplanowane ćwiczenia i aktywności do samodzielnego wykonania przez uczestnika kursu nie tylko wzbogacają treści, ale stanowią także czynnik angażujący i motywujący do samokształcenia. Materiały dydaktyczne przygotowane przez prowadzącego kurs mogą być przez niego rozbudowywane i usuwane w każdej chwili. Nauczyciel, który pełni rolę moderatora kursu, może także zarządzać treściami na kursie, to znaczy podzielić i udostępnić materiały w tym samym czasie lub ukryć i udostępnić w dowolnym czasie. Na platformie Moodle można prezentować treści $\mathrm{w}$ różnej formie, między innymi jako: dokumenty tekstowe, dokumenty w języku HTML, materiały informacyjne, plan kursu, harmonogram, zakładane efekty i cele kursu, załączniki w formatach: PDF, Word, Flash, PowerPoint, e-podręczniki, raporty, studia przypadku, symulacje oraz odnośniki do stron internetowych.

Kształcenie na platformie e-learningowej odbywa się w systemie asynchronicznym, czyli uczestnik kursu sam decyduje kiedy załączy kurs oraz ile czasu poświęci na czytanie materiałów i wykonywanie aktywności. Uczestnicy samodzielnie „określają” sobie czas na naukę, w zależności od innych swoich życiowych obowiązków. Taka forma nie ogranicza wirtualnego kontaktu z prowadzącym czy z grupą uczących się. Komunikacja odbywa się głównie poprzez fora dyskusyjne, a także pocztę e-mail. Forum dyskusyjne jest szczególnie istotnym narzędziem w nauczaniu asynchronicznym na platformie e-learningowej. Pozwala na wymianę informacji i opinii między uczestnikami kursu. Taka dyskusja jest najczęściej komunikacją jawną, to znaczy uczestnicy kursu czytają nawzajem swoje wypowiedzi, które są widoczne dla wszystkich zalogowanych na kurs. W celu dodatkowego zaktywizowania grupy, nauczyciel prowadzący kurs może taką dyskusję zaplanować w określonym czasie, na przykład na dwa tygodnie, po czym dyskusja zostaje zamknięta i nie ma możliwości dopisywania swojej odpowiedzi.

Platforma e-learningowa umożliwia także archiwizowanie treści w czasie określonym przez administratora platformy. Udział uczestników w poszczególnych aktywnościach może być dokładnie analizowany i raportowany prowadzącemu kurs. 


\section{Założenia metodologiczne}

Erall Babbi przyjmuje, że celem badania naukowego jest eksploracja, opis i wyjaśnienie problematyki badawczej ${ }^{7}$. W prezentowanym przypadku celem badań było poznanie, na ile platforma e-learningowa wraz z umieszczonymi na niej kursami języka polskiego jest interesującą i przystępną formą nauki dla osób mieszkających w Czechach, na Litwie i Łotwie, dla obywateli tych krajów, jak i osób pochodzenia polskiego. W badaniach zastosowano metodę sondażu diagnostycznego, technikę ankiety, a narzędziem był samodzielnie skonstruowany kwestionariusz ankiety. Kwestionariusz skonstruowano głównie na podstawie kafeterii dysjunktywnej (badany miał do wyboru jedną odpowiedź). Badanie przeprowadzono we wrześniu i październiku 2018 roku.

\section{Efektywność platformy e-learningowej w nauczaniu osób dorosłych - prezentacja wyników badań}

Kursy języka polskiego na platformie e-learningowej Moodle w ramach projektu Erazmus + „Wiedza bez barier - innowacyjne metody kształcenia osób dorosłych" zostały utworzone z myślą o Polakach mieszkających na Litwie, Łotwie i w Czechach, którzy przed laty stracili kontakt z językiem ojczystym, a obecnie znajdują się na emeryturze, czują się Polakami i nie chcą stracić kontaktu z poprawnym językiem. Kursy są przeznaczone także dla dorosłych osób, którzy są Litwinami, Łotyszami i Czechami od urodzenia, ale pracują i mieszkają na pograniczu lub w Polsce, którzy $\mathrm{z}$ racji wykonywanego zawodu lub zajmowanego stanowiska powinni posługiwać się poprawną polszczyzną. Założono, że odbiorcami kursu będą osoby dorosłe - od 18. roku życia do 68 lat i więcej. Przyjęto za cel przybliżanie zasad poprawności językowej i podniesienie kompetencji w zakresie posługiwania się językiem polskim. Głównym założeniem było przygotowanie i wdrożenie platformy e-learningowej, a na niej umieszczone kursy, które następnie powinny być rozbudowywane i współtworzone przez ich uczestników z różnych krajów. Do koordynacji platformy pod kątem merytorycznym wyznaczono wybranych wykładowców Akademii WSB. Projekt realizowano w latach 2016-2018. Kursy na platformie e-learningowej zostały ukończone w sierpniu 2018 roku i wtedy na platformę zalogowali się pierwsi użytkownicy. Kursy dla poszczególnych narodowości stanowią wybrane

${ }^{7}$ E.R. Babbie, The Practice of Social Reserch, Wadsworth/Thomson Learnig, All Rights Reserved, 2001, s. 112-113. 
zagadnienia fleksyjne, składniowe, leksykalne, sprawiające szczególne trudności użytkownikom polszczyzny na Litwie, Łotwie i w Czechach. W ramach kursów zaplanowano opanowanie wiedzy i słownictwa z różnych obszarów - od kultury po obszar kulinariów. Zakłada się, że trwanie i rozwój platformy e-learningowej przyczyni się do osiągnięcia większej sprawności komunikacji i rozbudzenia wrażliwości językowej. Dane dotyczące wieku badanych zawiera tabela 1.

Tabela 1

Charakterystyka badanej grupy (N 52)

\begin{tabular}{|c|c|c|c|c|c|c|}
\hline Wiek & $18-27$ lat & 28-37lat & $38-47$ lat & $48-57$ & $57-67$ & 68 i więcej \\
\hline $\begin{array}{l}\text { Procent } \\
\text { wskazań }\end{array}$ & $0 \%$ & $13,5 \%$ & $15,4 \%$ & $15,4 \%$ & $34,6 \%$ & $21,2 \%$ \\
\hline
\end{tabular}

Źródło: badania własne.

Na podstawie danych zawartych w tabeli można wnioskować, że w pierwszym tygodniu, kiedy kurs został udostępniony w przestrzeni internetowej, zalogowały się osoby w wieku powyżej 57 lat. Nikt z przedziału wieku między 18. a 27. rokiem życia nie wykazał zainteresowania kursem. Autorzy wnioskują, że taka sytuacja może wynikać z krótkotrwałego czasu funkcjonowania kursu na platformie, początkowego dostępu informacji o funkcjonowaniu platformy oraz braku czasu wolnego wśród osób młodych. Grupa uczestników do 30. roku życia to osoby żyjące niezwykle dynamicznie i zapewne korzystające z Internetu, jednak po „utartych” przez siebie ścieżkach (Facebook, Instagram, mail). Autorzy zakładają, że wraz z kampanią informacyjną i działaniami upowszechniającymi naukę języka polskiego dla Polaków poza granicami kraju (konferencje, publikacje, mailing) liczba osób będzie systematycznie wzrastać.

Autorzy przeanalizowali odpowiedzi 52 respondentów, którzy jako pierwsi zalogowali się i zapisali na kurs. Największą grupę zalogowanych stanowili Polacy (57\%), dalej Czesi (18\%), Łotysze (18\%) i Litwini (7\%). Z analizy badań wynika fakt nierównego rozłożenia się udziału procentowego osób pochodzenia polskiego w stosunku do uczestników projektu innych narodowości. Można wnioskować zatem, że kurs języka polskiego okazał się najbardziej potrzebny osobom, które mają polskie korzenie, a z racji życiowych doświadczeń nie mieszkają na terenie kraju być może od wielu lat. Autorzy wnioskują, że mogą być wśród nich osoby, które język ojczysty pamiętają tylko z przekazów rodziców i dziadków. Osoby te mogły podjąć decyzję o dokształceniu się z zasad swojego ojczystego języka, kiedy pojawiła się okazja, aby uczynić to bez kosztów i przemieszczania się z domu. 
Dane dotyczące opinii w dziedzinie narzędzia informatycznego, jakim jest platforma Moodle w kształceniu zdalnym osób zawiera tabela 2.

Tabela 2

Platforma jako narzędzie do nauczania (N 52)

\begin{tabular}{|l|c|c|c|c|c|}
\hline & $\begin{array}{c}\text { Zdecydo- } \\
\text { wanie } \\
\text { nie }\end{array}$ & Nie & $\begin{array}{c}\text { Nie mam } \\
\text { zdania }\end{array}$ & Tak & $\begin{array}{c}\text { Zdecydo- } \\
\text { wanie } \\
\text { tak }\end{array}$ \\
\hline $\begin{array}{l}\text { Czy Pani/Pana } \\
\text { zdaniem platforma } \\
\text { e-learningowa jest } \\
\text { odpowiednim narzę- } \\
\text { dziem do nauczania } \\
\text { osób dorosłych? }\end{array}$ & $0 \%$ & $3 \%$ & $13,8 \%$ & $50 \%$ & $32,8 \%$ \\
\hline
\end{tabular}

Źródło: badania własne.

Zdecydowana większość (83\%) przyznała, że platforma e-learningowa jest odpowiednim narzędziem do nauczania osób dorosłych. Zdecydowane tak wskazało $33 \%$ badanych. Jeden z głównych celów projektu został zatem osiągnięty. Mimo różnicy wiekowej i narodowościowej platforma jako narzędzie edukacji połączyła uczestników. Prawie wszyscy (92\%) stwierdzili, że rozwój kompetencji cyfrowych u osób dorosłych (np. umiejętność korzystania z programów komputerowych) poprawia jakość ich życia.

$\mathrm{Z}$ punktu widzenia badawczego interesujące było poznanie opinii na temat wykorzystania/zastosowania platformy e-learningowej Moodle do nauki języka polskiego (tab. 3).

Tabela 3

Opinie na temat platformy e-learningowej w kontekście nauki języka polskiego (N 52)

\begin{tabular}{|l|c|c|c|c|c|}
\hline & $\begin{array}{c}\text { Zdecydo- } \\
\text { wanie } \\
\text { nie }\end{array}$ & Nie & $\begin{array}{c}\text { Nie mam } \\
\text { zdania }\end{array}$ & Tak & $\begin{array}{c}\text { Zdecydo- } \\
\text { wanie } \\
\text { tak }\end{array}$ \\
\hline $\begin{array}{l}\text { Czy uważa Pani/Pan, } \\
\text { że nauka języka pol- } \\
\text { skiego za pomoca } \\
\text { platformy e-learningo- } \\
\text { wej jest efektywna? }\end{array}$ & $0 \%$ & $0 \%$ & $34,6 \%$ & $40,4 \%$ & $25 \%$ \\
\hline $\begin{array}{l}\text { Czy platforma } \\
\text { e-learningowa do na- } \\
\text { uki języka polskiego } \\
\text { powstała w ramach } \\
\text { projektu „Wiedza bez } \\
\text { barier"jest przyjazna } \\
\text { dla użytkownika? }\end{array}$ & $3,8 \%$ & $3,8 \%$ & $21,2 \%$ & $53,8 \%$ & $17,3 \%$ \\
\hline
\end{tabular}




\begin{tabular}{|l|l|l|l|l|l|}
\hline $\begin{array}{l}\text { Czy platforma } \\
\text { e-learningowa do na- } \\
\text { uki języka polskiego } \\
\text { powstała w ramach } \\
\text { projektu „Wiedza bez } \\
\text { barier" pozwala popra- } \\
\text { wić kompetencje cyfro- } \\
\text { we użytkownika? }\end{array}$ & $0 \%$ & $0 \%$ & $23,1 \%$ & $50 \%$ & $26,9 \%$ \\
\hline
\end{tabular}

Źródło: badania własne.

Dane potwierdzają, że nauka języka polskiego za pomocą platformy e-learningowej jest nauką efektywną. Tak i zdecydowanie tak odpowiedziało $65 \%$ badanych. Co interesujące z badawczego punktu widzenia, żaden uczestnik badania nie wskazał, iż platforma e-learningowa w kontekście nauki języka polskiego jest nieefektywna, a jedynie $34,6 \%$ stwierdziło, że nie ma zdania w powyższej kwestii. Można zatem wnioskować, że platforma e-learningowa stanowi dobre narzędzie edukacyjne, oceniane jako trafne i sprzyjające efektywności.

Interesujące okazały się wyniki dotyczące oceny przyjazności platformy jako narzędzia edukacyjnego. Największą grupę respondentów badań stanowiły bowiem osoby po pięćdziesiątym roku życia. Wstępna analiza oczekiwañ $^{8} \mathrm{w}$ zakresie kształcenia zdalnego osób dorosłych pozwalała wnioskować, iż użytkownicy platformy będą posiadali ograniczone umiejętności $\mathrm{w}$ zakresie posługiwania się narzędziami informatycznymi. Wyniki badań nie potwierdziły tego założenia. Ponad $70 \%$ osób oceniło platformę jako przyjazne narzędzie edukacyjne.

Twórcy projektu Erazmus + „Wiedza bez barier - innowacyjne metody kształcenia osób dorosłych" zakładali działania upowszechniające, jak i proces transferu wiedzy pomiędzy uczestnikami projektu, ale również w systemie powszechnej dostępności ${ }^{9}$. Jak wynika z badań, 73\% badanych stwierdziło, że platforma e-learningowa może być nadal rozwijana i poszerzana o nowe kursy po zakończeniu projektu.

W kształceniu osób dorosłych istotna jest międzypokoleniowość. W przedstawianym przypadku ma ona znaczenie tym większe, iż dotyczy Polaków mieszkających poza granicami. Dane przedstawia tabela 4.

Kursy na platformie e-learningowej Moodle w ramach projektu Erazmus + „Wiedza bez barier - innowacyjne metody kształcenia osób dorosłych" są dedykowane dla osób dorosłych i młodego pokolenia. Chociaż w pierwszej

${ }^{8}$ Dane dotyczące kompetencji w zakresie posługiwania się narzędziami, jak i wstępnych oczekiwań znajdują się w raporcie przejściowym z projektu (2017 r.).

${ }^{9}$ Uczestnictwo w kursie jest darmowe i ogólnodostępne. 
Międzypokoleniowość na platformie e-learningowej (N 52)

\begin{tabular}{|l|c|c|c|c|c|}
\hline & $\begin{array}{c}\text { Zdecydo- } \\
\text { wanie } \\
\text { nie }\end{array}$ & Nie & $\begin{array}{c}\text { Nie mam } \\
\text { zdania }\end{array}$ & Tak & $\begin{array}{c}\text { Zdecydo- } \\
\text { wanie } \\
\text { tak }\end{array}$ \\
\hline $\begin{array}{l}\text { Czy Pani/Pana } \\
\text { zdaniem wspólne } \\
\text { kształcenie w grupach } \\
\text { międzypokoleniowych } \\
\text { (np. juniorzy wspólnie } \\
\text { z seniorami) jest efek- } \\
\text { tywne dla obu stron? }\end{array}$ & $1,7 \%$ & $3,4 \%$ & $19 \%$ & $39,7 \%$ & $36,2 \%$ \\
\hline
\end{tabular}

Źródło: badania własne.

fazie trwania projektu na platformie zalogowały się głównie osoby po 50 . roku życia, to jednak zdecydowana większość zalogowanych (75\%) stwierdziła, że wspólne kształcenie w grupach międzypokoleniowych, czyli juniorzy wspólnie z seniorami, jest efektywne dla obu stron. Autorzy są zdania, że taka forma nauki może łączyć generacje i stanowić odpowiedź na wyzwania współczesności, na lepsze budowanie relacji między starszym a młodszym pokoleniem. Tylko 1,7\% wskazało, że kształcenie w grupach międzypokoleniowych jest nieefektywne. W Polsce, podobnie jak w Europie, zanikają rodziny wielopokoleniowe, a wiedza starszych osób, gromadzona przez całe życie, szybko się dezaktualizuje. Seniorzy przestają być postrzegani jako „skarbnica wiedzy i mądrości". Powszechnie zauważa się zatem brak naturalnych przestrzeni do kontaktów wielopokoleniowych, zarówno na gruncie rodziny jak i zawodowym. Badani potwierdzają, że wspólna nauka na platformie e-learningowej może stanowić okazję do wymiany doświadczeń i współpracy międzypokoleniowej. W czasie spotkań sieciujących w trakcie trwania projektu wynikało, że młode pokolenie bardzo chętnie włącza się w proces edukacji dorosłych (pomoc przy tworzeniu kursu języka polskiego).

\section{Zakończenie}

Realizacja projektu Erazmus + „Wiedza bez barier - innowacyjne metody kształcenia osób dorosłych" pozwala wnioskować, że uczestniczenie w kursach zdalnych wiąże się z rozwojem kompetencji cyfrowych, w tym z opanowaniem elementarnego słownictwa informatycznego (przełamywanie lęków i barier w tym obszarze). Uczestnicy projektu sami współtworzyli kursy nauki języka polskiego, wzbogacając je o autorskie moduły, jak na przykład 
pogotowie językowe, tłumacz, kuchnia polska po czesku (http://www.wiedzabezbarier.eu). Nauka języka polskiego na platformie e-learningowej dała okazję uczestnikom do poszerzenia wiedzy i zainteresowań bez wychodzenia z domu, niezależnie od miejsca zamieszkania i stopnia sprawności fizycznej. Pierwsi zalogowani uczestnicy projektu bardzo pozytywnie ocenili platformę e-learningową jako narzędzie edukacyjne. Niezależnie od narodowości i cyfrowego doświadczenia, kursanci zweryfikowali platformę jako efektywną i przyjazną.

Autorzy formułują konkluzję, iż mimo braku fizycznej obecności użytkowników, aktywność na kursach zdalnych może pomóc w rozwoju komunikacji międzypokoleniowej między użytkownikami Sieci (obsługiwanie poczty elektronicznej, obsługiwanie portali społecznościowych, korzystanie z programów do komunikacji zdalnej typu SKYPE).

Uczestnicy projektu Erazmus + „Wiedza bez barier - innowacyjne metody kształcenia osób dorosłych" potwierdzili wysoką funkcjonalność platformy e-learningowej w nauczaniu pozaformalnym dorosłych. Internet, jak wynika z badań, poprawia jakość życia i pozwala na rozwój osobisty. Dzięki korzystaniu z Sieci osoby dojrzałe uczą się nowych rzeczy, a także włączają w życie społeczności. Uczestnictwo $\mathrm{w}$ projekcie było także okazją do wymiany doświadczeń ze współpracy międzyorganizacyjnej, sieciowej, w partnerstwie naukowo-społecznym (międzypokoleniowym i międzynarodowym), jak też obserwacji i wniosków związanych z wdrożeniem platformy e-learningowej.

Na podstawie częściowej analizy badań, $\mathrm{w}$ fazie ich trwania, można wnioskować, że platforma e-learningowa jako narzędzie w nauczaniu zdalnym osób dorosłych jest odpowiedzią na coraz to większe wyzwania stojące przed edukacją człowieka dorosłego.

\section{BIBLIOGRAFIA}

Aleksander T., Teoretyczne i praktyczne aspekty edukacji kulturalnej oraz oświaty dorostych, Wydawnictwo Uniwersytetu Jagiellońskiego, Kraków 2006.

Aleksander T., Andragogika: podręcznik akademicki, Instytut Technologii Eksploatacji - Państwowy Instytut Badawczy, Radom 2009.

Babbie E.R., The Practice of Social Reserch, Wadsworth/Thomson Learnig, All Rights Reserved 2001.

Bąk A., Hołda M., Seniorzy w sieci. Między stereotypem a prawda, [w:] Człowiek zalogowany. Od mowy nienawiści do integracji w sieci, Biblioteka Jagiellońska, Kraków 2013.

Boczukowa B., Jak ksztatcić dorostych, refleksje andragoga, Wydawnictwo Adam Marszałek, Toruń 2010.

Borczyk W., Wnuk W., Edukacja w starości i do starości, [w:] Strategie działania w starzejacym się społeczeństwie. Tezy i rekomendacje, Wydawnictwo Rzecznika Praw Obywatelskich, Warszawa 2012. 
Czarkowski J.J., E-Learning dla dorostych, Wydawnictwo Difin, Warszawa 2012.

https://pl.wikipedia.org/wiki/Moodle [dostęp: 02.12.2018].

http://www.wiedzabezbarier.eu

Juszczyk S. (2003), Edukacja na odległość, Wydawnictwo Adam Marszalek, Toruń 2012.

Kurasz I., Edukacja dorostych wobec problemów globalizacji, [w:] Andragogika w ujęciu interdyscyplinarnym, red. W. Horyń, J. Maciejewski, Wydawnictwo Uniwersytetu Wrocławskiego, Wrocław 2007.

Kryston M., Serak M., Tomczyk Ł., Nowe trendy w edukacji seniorów, Czesko-Polsko-Słowackie studia z zakresu andragogiki i gerontologii społecznej, Kraków 2014.

Malec M., Edukacyjne, kulturowe i społeczne konteksty starości, Oficyna Wydawnicza ATUT-Wrocławskie Wydawnictwo Oświatowe, Wrocław 2011.

Malewski M., Teorie andragogiczne. Metodologia teoretyczności dyscypliny naukowej, Wydawnictwo Uniwersytetu Wrocławskiego, Wrocław 1998.

Malewski M., Od nauczania do uczenia się, o paradygmatycznej zmianie w andragogice, Wydawnictwo Naukowe Dolnośląskiej Szkoły Wyższej, Wrocław 2010.

Meger Z., Zmieniająca się rola nauczyciela w warunkach przeobrażeń technologicznych, [w:] Być nauczycielem - opiekunem - wychowawca. Między teoria a praktyka, red. G. Durka, E. Murawska, Wydawnictwo Adam Marszałek, Torun 2012.

Paluchowski J., Internet a psychologia, Wydawnictwo Naukowe PWN, Warszawa 2009.

Prensky M., Digital Natives, Digital Immigrants, [w:] Jak będzie się zmieniać edukacja, red. W. Kołodziejczyk, M. Polak, Wydawnictwo Instytut Obywatelski, Warszawa 2001.

Siemieniecki B., Komputer w edukacji: Podstawowe problemy technologii informacyjnej, Wydawnictwo Adam Marszałek, Toruń 2002.

Siemieniecki B., Technologia informacyjna w polskiej szkole: Stan i zadania, Wydawnictwo Adam Marszałek, Torun 2003.

Stopińska-Pająk A., Chowanna t. II - Edukacja wobec starości, tradycja i wspótczesność, Wydawnictwo Uniwersytetu Śląskiego, Katowice 2009.

Szmigielska B., Senior zalogowany, Wydawnictwo Uniwersytetu Jagiellońskiego, Kraków 2014.

Śliwerski B., Jak zmieniać szkołę? Studia z polityki oświatowej i pedagogiki porównawczej, Oficyna wydawnicza Impuls, Kraków 2008.

Tomczyk Ł., Edukacja osób starszych, Wydawnictwo Difin, Warszawa 2015.

Włodarski Z., Psychologia uczenia się, Wydawnictwo Naukowe PWN, Warszawa 1998. 
